\title{
Improved plant regeneration in callus cultures of Sorghum bicolor (L.) Moench
}

\author{
Mariola Dreger $^{1} \cdot$ Rafał Mól $^{2} \cdot$ Aleksandra Deja $^{1} \cdot$ Ewa Raj $^{2} \cdot$ Grażyna Mańkowska $^{1} \cdot$ Karolina Wielgus $^{1}$
}

Received: 11 July 2018 / Accepted: 4 January 2019 / Published online: 26 February 2019 / Editor: Yong Eui Choi

(C) The Author(s) 2019

\begin{abstract}
Sorghum bicolor is a recalcitrant species for tissue culture regeneration and genetic transformation. Browning of explants is one of the factors limiting organ and tissue cultures. To overcome this, callus tissue was initiated from the shoot tips of in vitro germinating seeds (S. bicolor cv. Róna 1), and then cultured on modified MS media (Murashige and Skoog in Physiol Plant 15:473-497, 1962). In the first experiment, we tested callus induction on several media supplemented with casein hydrolysate, polyvinylpyrrolidone, honey, and sucrose. The best callus induction was recorded for the medium with honey and sucrose (80.0\%) and for control medium (79.8\%). Shoot regeneration was tested on the MS medium with 6-benzylaminopurine (BAP) supplemented with honey and sucrose at a 1:1 ratio (by weight) or with sucrose only. The highest percentage of calluses regenerating shoots was noted for those induced on the medium with sucrose and honey-approx. four times higher when compared to the control. Rooted plantlets were acclimatized with a $92 \%$ survival rate. In the second experiment, we analyzed culture responses to various ways of honey application to the induction media: honey (autoclaved or filtered) in presence or absence of sucrose. Supplementation of the medium with fructose, glucose, and maltose at a proportion typical for honey was also investigated. The explant and callus survival rates were similar to those of the honey-sucrose combination in the first experiment. Only presence of both sucrose and honey in the induction medium improved the total regeneration rate to $37.9 \%$ over the control (18.8\%). Sucrose and honey appear to act synergistically for shoot regeneration in callus cultures of sorghum.
\end{abstract}

Keywords Sorghum bicolor $\cdot$ Callus induction $\cdot$ Shoot regeneration $\cdot$ Honey

\section{Introduction}

Sorghum bicolor (L.) Moench (Poaceae) is one of the most important cereal crops. Due to high temperature and drought tolerance, sorghum is considered as one of the most successful crops in the semi-arid regions of Africa and Asia (Rao et al. 2015). S. bicolor is a C4 plant, highly efficient in water use and biomass production. It is well adapted to water-deficient environments and thus is one of the crops capable of adapting to climate changes. Sorghum is also used as feedstock for

Mariola Dreger

mariola.dreger@iwnirz.pl

1 Department of Biotechnology, Institute of Natural Fibres and Medicinal Plants, Wojska Polskiego 71b, 60-630 Poznan, Poland

2 Department of General Botany, Institute of Experimental Biology, Faculty of Biology, Adam Mickiewicz University, Umultowska 89, 61-614 Poznan, Poland biofuel production. Ethanol produced from sweet sorghum is cheaper, quicker to produce, and poses little risk to the environment compared to maize or sugarcane (Rao et al. 2015). However, sorghum is considered as one of the most resistant species for tissue culture regeneration and genetic transformation. Genotype-dependent polyphenol production and tissue browning are the main limitations to in vitro propagation of S. bicolor. This results in poor response of the explants and a low regeneration rate. Efficient and reproducible regeneration protocols are essential for successful genetic transformation in crop yield improvements. Nevertheless, there are a number of reports on Sorghum regeneration via embryogenic callus from different explants: immature inflorescence (Elkonin et al. 1995; Raghavendra Rao et al. 2000), immature embryos (Hagio 2002; Grootboom et al. 2008; Sudhakar Pola et al. 2008), shoot tips, or meristem (Cai et al. 1987; Seetharama et al. 2000; Zhong et al. 1998; Maheswari et al. 2006). Generally, immature inflorescences and immature embryos are considered as the first choice explants because they have the highest regenerative capacity. However, production and 
availability of these types of explants are usually limited by a narrow time window-a short time before (inflorescence) or after pollination (embryos). Moreover, fresh plant material is not suitable for storage. Therefore, explants derived from seeds are definitely more convenient and suitable (Zhong et al. 1998; Maheswari et al. 2006; Liu et al. 2015). Although significant progress has been made in studies on Sorghum tissue culture, a simple and efficient regenerative system is still needed.

There are two main strategies to improve the response of callus and its regenerative capacity: genotype selection of explant donors and media modifications. Genotype selection has been mainly focused on the cultivars and genotypes which show high ability of plant regeneration and low or non-tannin accumulation. Hagio (2002) chose two genotypes, C. Kafir and PE932025, among 11 varieties due to the highest ability of callus formation and plant regeneration. The non-tannin $\mathrm{T} \times 430$ inbred line has usually been chosen for tissue culture and genetic transformation (Howe et al. 2006; Liu and Godwin 2012; Wu et al. 2014). A number of media modifications have been reported as efficient in improvement of callus regeneration ability. A beneficial effect of the amino acids: proline and asparagine on embryogenic callus proliferation was reported by Elkonin et al. (1995). The levels of $\mathrm{NO}_{3}{ }^{-}$ and the $\mathrm{NO}_{3}{ }^{-}$to $\mathrm{NH}_{4}{ }^{+}$ratio in the media supplemented with L-asparagine and L-proline were also found to be critical factors for embryonic callus formation (Elkonin and Pakhomova 2000). An advantageous effect of $\mathrm{CuSO}_{4} 5 \mathrm{H}_{2} \mathrm{O}$ L-asparagine and L-cysteine on callus growth and shoot production was reported by Liu et al. (2015). The authors also highlighted that callus age plays a key role in growth and shoot regeneration capacity.

The carbon source also plays an important role in plant in vitro organogenesis. Exogenously added sugars into media might be influential on organ differentiation and efficiency of in vitro regeneration. Honey is a natural source of sugars, enzymes, amino acids, organic acids, vitamins, and minerals. A beneficial effect of honey as a medium additive was earlier reported for callus induction and plant regeneration in Miscanthus $\times$ giganteus (Płażek and Dubert 2010), and also for in vitro plantlet formation in an orchid, Encyclea cordigera (Mantovani and Fernandes Lopes Pivetta 2016).

Hence, the aim of this study was to improve callus induction and plant regeneration of the sorghum cultivar Róna 1, which is commonly used in Europe as a feedstock for biofuel production (energy plant) as well as feed crop. The regeneration protocol was developed for seedling shoot apices, which are easily available and suitable for callus formation. In two independent experiments, media supplements were tested: Experiment 1-honey, polyvinylpyrrolidone (PVP), and casein hydrolysate; Experiment 2 - various sugar forms including honey. The optimized regeneration protocol for $S$. bicolor
L. cv. Róna 1 was developed using honey as the medium additive. The combination of sucrose and honey in the callus induction medium significantly improved the regenerative capacity of the callus, which is reported here for the first time in sorghum.

\section{Materials and Methods}

Plant material In this study, Sorghum bicolor seeds (cv. Róna 1) were used. The seeds were provided by Cereal Research Non-profit Ltd. (Szeged, Hungary). Due to the best callus formation, Róna 1 was chosen out of four cultivars (Hercules, Santos, Sucrosorgo 506, Róna 1) in the preliminary tests for in vitro callus induction and shoot regeneration (data not shown).

Testing of various media supplements (Experiment 1) Seeds were surface sterilized with $70 \%$ ethanol and commercial bleach (ACE, Fater SpA, Pescara, Italy) and then washed 3-4 times in autoclaved water. Sterilized seeds were germinated on petri dishes containing full-strength MS basal medium (Murashige and Skoog 1962) with no plant growth regulators. Shoot tips derived from two-day old seedling were used as explants for callus induction (Fig. 1a). Shoot tips $(0.1-0.2 \mathrm{~cm})$ including shoot meristem, leaf primordia, coleoptile, and a small part of the mesocotyl were cut off from the seedlings and placed on an induction medium in the vertical orientation. The control medium was full-strength MS basal medium supplemented with 2,4-dichlorophenoxyacetic acid (2,4-D) at concentration $2.0 \mathrm{mg} \mathrm{L}^{-1}$, kinetin $\left(0.2 \mathrm{mg} \mathrm{L}^{-1}\right)$, proline (1.0 $\left.\mathrm{g} \mathrm{L}^{-1}\right)$, vitamin $\mathrm{C}\left(0.1 \mathrm{~g} \mathrm{~L}^{-1}\right)$, sucrose $\left(30 \mathrm{~g} \mathrm{~L}^{-1}\right)$, and Bacto $^{\mathrm{TM}}$ Agar $\left(8 \mathrm{~g} \mathrm{~L}^{-1}\right)$. Casein hydrolysate $\left(1.0 \mathrm{~g} \mathrm{~L}^{-1}\right)$, polyvinylpyrrolidone $\left(1.0 \mathrm{~g} \mathrm{~L}^{-1}\right)$, honey $\left(15.0 \mathrm{~g} \mathrm{~L}^{-1}\right)$, and additional sucrose $\left(15.0 \mathrm{~g} \mathrm{~L}^{-1}\right)$ were added into the control medium to test the effect of medium composition on the induction and regenerative potential of calluses (Table 1). Multifloral honey was derived from a commercial apiary and stored in a fridge. All the chemicals were supplied by Sigma-Aldrich Ltd., Co., St. Louis, MO except Bacto ${ }^{\text {TM }}$ Agar (BD, Becton, Dickinson and Company, Sparks, MD) and vitamin C (POCH S. A., Gliwice, Poland). The $\mathrm{pH}$ of the media was adjusted to 5.8 before autoclaving at $121^{\circ} \mathrm{C}$ at $0.1 \mathrm{MPa}$ for $20 \mathrm{~min}$. Seed germination and callus induction proceeded in darkness at $25 \pm$ $2^{\circ} \mathrm{C}$. For each treatment, 100 explants were planted on 10 petri dishes as replicates (10 explants per dish). Each treatment was done at least in triplicate. After $3 \mathrm{wk}$. of incubation, non-fragmented calluses were subcultured on the fresh regeneration media (R1 and R2; Table 1). Then the survival rates, percentages of callus-forming explants, and percentages of shoot-forming calluses (regeneration 
Figure 1. Callus induction and plant regeneration of $S$. bicolor: (a) germinating seeds; (b) browning explants on S45 medium after $5 \mathrm{~d}$ of incubation, note phenolic substances released by the explants into the medium (black color); (c) developing callus on SH medium after $10 \mathrm{~d}$ of incubation; $(\boldsymbol{d})$ callus (arrowheads) on $\mathrm{SH}$ medium after 3 wk. of incubation; (e) callus regenerating shoots on $\mathrm{R} 2$ medium; $(f)$ regenerated plants after 3 wk. of acclimatization in soil.

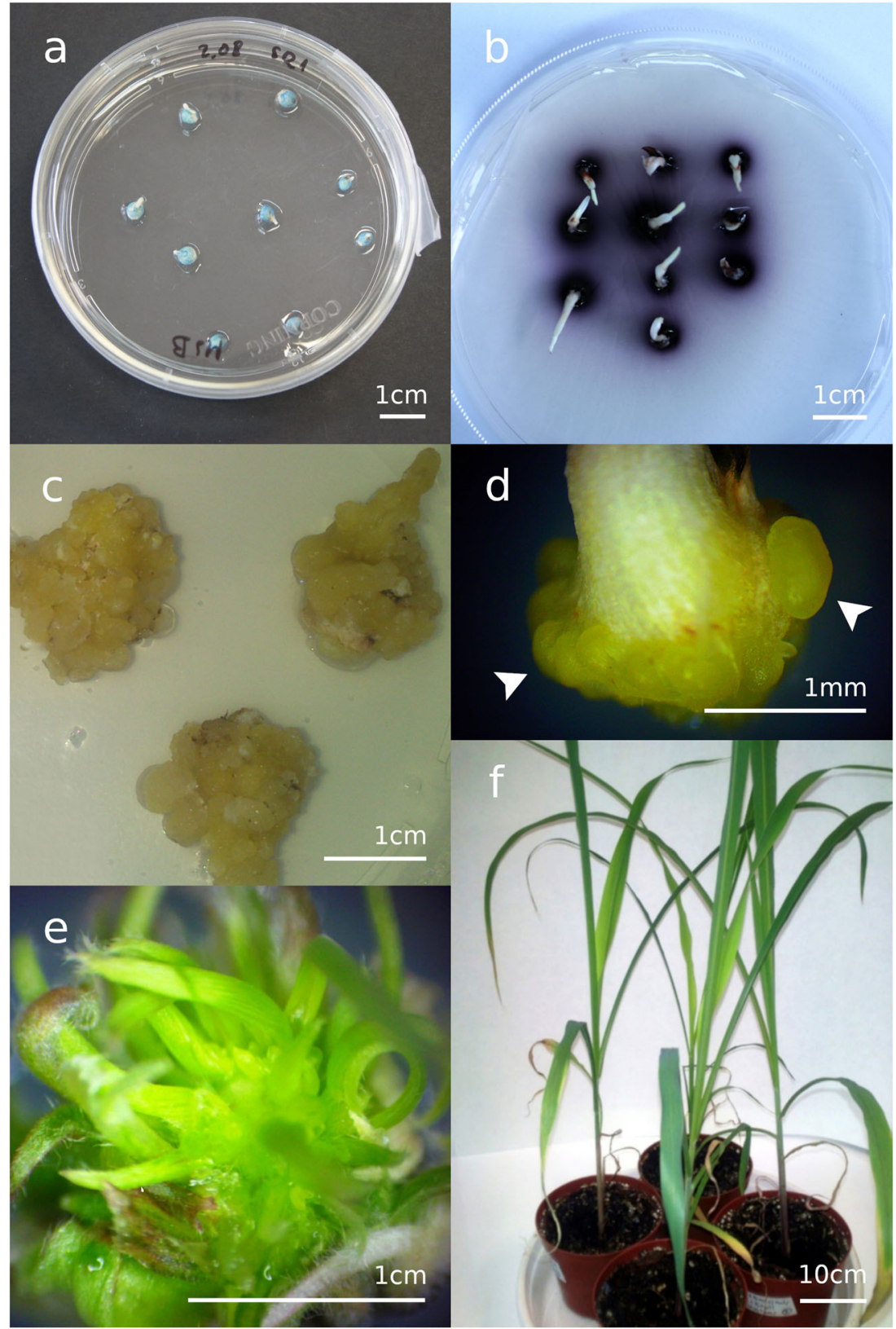

rates) were calculated. Calluses forming shoots were transferred into Magenta vessels containing the rooting medium: half-strength MS medium with indole-3-acetic acid (IAA; $\left.0.5 \mathrm{mg} \mathrm{L}^{-1}\right)$ and vitamin $\mathrm{C}\left(0.1 \mathrm{mg} \mathrm{L}^{-1}\right)$. Shoots formed on the calluses derived from the individual explants were counted after 4 wk. of culture, and the average numbers of shoots per explant were calculated. The total number of explants was 93 (31 explants for each replicate). Plant regeneration and rooting proceeded at $25^{\circ} \mathrm{C} \pm 2{ }^{\circ} \mathrm{C}$ with a $16 \mathrm{~h}$ photoperiod under a photosynthetic flux of $120 \mu \mathrm{mol} \mathrm{m} \mathrm{s}^{-1}$ (daylight fluorescent tubes). Regenerated shoots on the R1 and R2 media were rooted. Regenerants were transferred into sterile soil in pots covered with glass cups and acclimatized under the same conditions. After 2 wk., the cups were removed. The percentage of acclimatized plants was counted after $3 \mathrm{wk}$. of acclimatization.

Optimization of media supplementation with honey (Experiment 2) Callus was induced as described in Experiment 1. Five induction media were investigated in order to improve the callus regeneration rate (Table 1). Control and $\mathrm{SH}$ (containing sucrose $30.0 \mathrm{~g} \mathrm{~L}^{-1}$ and honey $15.0 \mathrm{~g} \mathrm{~L}^{-1}$, Table 1) media were used as in Experiment 1. Three other media were also tested: FH medium with addition of sterile filtered honey $\left(0.22 \mu \mathrm{m}\right.$; Corning ${ }^{\circledR}$, 
Table 1. Composition of media used in experiments

\begin{tabular}{|c|c|}
\hline Media & Composition \\
\hline \multicolumn{2}{|c|}{ Callus induction media } \\
\hline $\mathrm{C}$ & MS medium, 2,4-D $\left(2.0 \mathrm{mg} \mathrm{L}^{-1}\right)$; kin $\left(0.2 \mathrm{mg} \mathrm{L}^{-1}\right)$, vitamin $\mathrm{C}\left(0.1 \mathrm{~g} \mathrm{~L}^{-1}\right)$, proline $\left(1.0 \mathrm{~g} \mathrm{~L}^{-1}\right) ; 30 \mathrm{~g} \mathrm{~L}^{-1}$ sucrose, $8 \mathrm{~g} \mathrm{~L}^{-1}$ agar \\
\hline S45 & C medium with additional $15 \mathrm{~g} \mathrm{~L}^{-1}$ sucrose (total $45 \mathrm{~g} \mathrm{~L}^{-1}$ ) \\
\hline $\mathrm{SH}$ & C medium plus $15 \mathrm{~g} \mathrm{~L}^{-1}$ honey (autoclaved) \\
\hline PVP & C medium with PVP $\left(1 \mathrm{~g} \mathrm{~L}^{-1}\right)$ \\
\hline $\mathrm{CH}$ & C medium with casein hydrolysate $\left(1 \mathrm{~g} \mathrm{~L}^{-1}\right)$ \\
\hline FH & C medium plus $15 \mathrm{~g} \mathrm{~L}^{-1}$ honey (filter-sterilized) \\
\hline $\mathrm{H} 30$ & $\mathrm{C}$ medium with honey $\left(30 \mathrm{~g} \mathrm{~L}^{-1}\right)$ instead of sucrose \\
\hline $\mathrm{IM}$ & C medium with fructose $\left(16.2 \mathrm{~g} \mathrm{~L}^{-1}\right)$, glucose $\left(13.1 \mathrm{~g} \mathrm{~L}^{-1}\right)$, and maltose $\left(0.8 \mathrm{~g} \mathrm{~L}^{-1}\right)$ instead of sucrose \\
\hline \multicolumn{2}{|c|}{ Regeneration media } \\
\hline $\mathrm{R} 1$ & MS medium, BAP $\left(2.0 \mathrm{mg} \mathrm{L}^{-1}\right), 30 \mathrm{~g} \mathrm{~L}^{-1}$ sucrose \\
\hline $\mathrm{R} 2$ & MS medium, BAP $\left(2,0 \mathrm{mg} \mathrm{L}^{-1}\right)$ with sucrose $\left(15 \mathrm{~g} \mathrm{~L}^{-1}\right)$, and honey $\left(15 \mathrm{~g} \mathrm{~L}^{-1}\right)$ \\
\hline \multicolumn{2}{|c|}{ Rooting medium } \\
\hline RT & $1 / 2$ MS medium with IAA $\left(0.5 \mathrm{~g} \mathrm{~L}^{-1}\right)$; vitamin $\mathrm{C}\left(0.1 \mathrm{~g} \mathrm{~L}^{-1}\right), 15 \mathrm{~g} \mathrm{~L}^{-1}$ sucrose, $8 \mathrm{~g} \mathrm{~L}^{-1}$ agar \\
\hline
\end{tabular}

MS MS basal medium (Murashige and Skoog 1962), 2,4-D dichlorophenoxyacetic acid, kin kinetin, PVP polyvinylpyrrolidone, BAP 6benzylaminopurine, IAA indole-3-acetic acid

Keiserslauten, Germany), H30 medium with honey instead of sucrose (30.0 $\left.\mathrm{g} \mathrm{L}^{-1}\right)$, and IM medium with predominant honey sugars (fructose, glucose, and maltose), as presented in Table 1. Regeneration and rooting were proceeded as described in Experiment 1. For each treatment, 70 explants were put on petri dishes as replicates (10 explants per dish). Each treatment was done in triplicate.

Microscopic preparation of explants and callus The explants, i.e., the shoot tips dissected directly from in vitro germinated seedlings, and the callusing explants cultured for $4 \mathrm{wk}$. on a callus-inducing medium, as well as 3-wk old calluses cultured for 7 or $10 \mathrm{~d}$ on the regeneration medium, were collected and fixed in FAA (ethanol 70\%/formalin 40\%/glacial acetic acid as 90:5:5 by vol.) for $48 \mathrm{~h}$. The fixed material was dehydrated in an ethanol series (70-80-90-96\% $1 \mathrm{~h}$ each, and absolute ethanol $2 \times$ $30 \mathrm{~min})$, then cleared in absolute ethanol + butanol solutions $(3: 1,1: 1,1: 3$ by vol.) for $1 \mathrm{~h}$ each, followed by two 30-min rinses in butanol. Samples were stored in butanol overnight, and then infiltrated by Paraplast ${ }^{\circledR}$ (SigmaAldrich Chemie $\mathrm{GmbH}$, Steinheim, Germany) at $55^{\circ} \mathrm{C}$ (three changes for $3 \mathrm{~h}$, one change overnight, one change for $48 \mathrm{~h}$ ). The embedded samples were cut on a rotary microtome (Leica Biosystems Nussloch GmbH, Nussloch, Germany), and the slides with $12 \mu \mathrm{m}$-thin serial sections were stained in safranin and fast green according to Jensen (1962). Stained sections were mounted in Entellan® (Merck KGaA, Darmstadt, Germany) for permanent slides. Microphotographs were made with the ZEISS setup of MRC5 camera and Axioscope.
Analyses of honey Honey samples were analyzed at the Research Institute of Horticulture in Puławy (Poland) according to the Polish standard (PN-88/A-77626) and to the Regulation of the Ministry of Agriculture and Rural Development (Dz.U.09.17.94). The assays of honey sugars were run using HPLC with a refractometer detector (HPLC RI). The content of sugars in samples $(5.0 \mathrm{~g})$ was quantified as grams of sugar per 100-g dry weight (g $100 \mathrm{~g}^{-1} \mathrm{DW}$ ) (Table 2). The retention times, UV spectra, and ion mass spectra of the sugars were compared with those of authentic standards. The content of proline in samples $(2.5 \mathrm{~g})$ was quantified using the colorimetric method and expressed as fresh weight (g $\left.100 \mathrm{~g}^{-1} \mathrm{FW}\right)$.
Table 2. Standard parameters measured in honey samples

\begin{tabular}{|c|c|}
\hline Content of & Value \\
\hline Water & $15.1 \%$ \\
\hline Fructose & $37.0{\mathrm{~g} 100 \mathrm{~g}^{-1} \mathrm{DW}}$ \\
\hline Glucose & $37.02{\mathrm{~g} 100 \mathrm{~g}^{-1} \mathrm{DW}}$ \\
\hline Sucrose & Not detected \\
\hline Turanose & 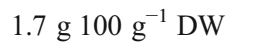 \\
\hline Maltose & $1.5{\mathrm{~g} 100 \mathrm{~g}^{-1} \mathrm{DW}}$ \\
\hline Trehalose & 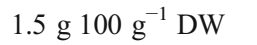 \\
\hline Isomaltose & $0.6{\mathrm{~g} 100 \mathrm{~g}^{-1} \mathrm{DW}}$ \\
\hline Melezitose & $<0.5{\mathrm{~g} 100 \mathrm{~g}^{-1} \mathrm{DW}}^{-}$ \\
\hline Erlose & 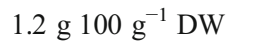 \\
\hline Raffinose & Not detected \\
\hline Total sugars & 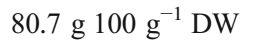 \\
\hline Proline & $44.0 \mathrm{mg} 100 \mathrm{~g}^{-1} \mathrm{FW}$ \\
\hline Diastase number & 20.7 Schade units \\
\hline
\end{tabular}


Table 3. Species participation in pollen content of honey

\begin{tabular}{lll}
\hline Species & Average number of pollen grains & $\%$ \\
\hline Phacelia sp. & 125.0 & 39.7 \\
Brassica napus & 114.0 & 36.2 \\
Trifolium pratense & 13.0 & 4.1 \\
Frangula sp. & 11.5 & 3.7 \\
Centaurea cyanus & 8.5 & 2.7 \\
Malus sp. & 8.0 & 2.5 \\
Salix sp. & 7.5 & 2.4 \\
Prunus sp. & 7.5 & 2.4 \\
Acer sp. & 7.5 & 2.4 \\
Vicia faba & 4.0 & 1.3 \\
Others & 8.0 & 2.5 \\
Total & 314.5 & 100.0 \\
\hline
\end{tabular}

Content of water in honey was expressed as $\%(w / v)$ and determined in the refractometric assay (Table 2). Diastase activity (diastase number) was calculated in Schade units (Schade et al. 1958) as a result of the spectrophotometric assay (Phadebas). Microscopic examination of pollen was performed, and content in percentage of pollen species and average number of grains (average value of two analyses) are presented in Table 3.

Statistical analyses The non-parametric Mann-Whitney $U$ test and the Kruskal-Wallis test were used since the distribution of variables was non-normal (which was verified with the Shapiro-Wilk test). The Mann-Whitney $U$ test was performed for comparisons between the two groups, while the Kruskal-Wallis test was used when the number of compared groups was higher than two. The post hoc analysis was evaluated by Dunn's multiple comparison test. The significance level was 0.05. All statistical analysis was performed using STATISTICA 10 (StatSoft Inc., Tulsa, OK; 2011).

\section{Results}

Callus induction and regeneration (Experiment 1) In this experiment, addition of sucrose, honey, PVP, and casein hydrolysate into an induction medium was tested. Callus was observed on all tested media except S45 with additional sucrose (total of $45.0 \mathrm{~g} \mathrm{~L}^{-1}$ ) (Table 4). The explants on the S45 medium darkened within $5 \mathrm{~d}$ and secreted phenolics which were visible around the explants (Fig. 1b). At the end of incubation, only $55 \%$ of them survived, but no callus was observed. On the other four media tested, only occasional darkening of explants was noted, and creamy, compact callus developed at the base of explants within the first 2 wks of incubation (Fig. 1c, d). Anatomical analysis of the explants (Fig. 2) revealed that callus tissue was mainly induced from leaf primordia and elongating mesocotyl where new meristematic centers or regions were formed (Fig. 3). In some samples, also, the shoot apical meristem became larger, which suggests its possible participation in callus production. De novo formation of shoots appeared on regeneration media, as no structures growing on the callus met the criteria for somatic embryogenesis (Haccius 1978).

The best response of explants (79-80\%) was noted for control medium (C) and medium with honey $(\mathrm{SH})$, followed by PVP and $\mathrm{CH}$ medium (Table 4). Calluses induced on four media (named as C-, SH-, PVP-, and $\mathrm{CH}$-callus) were separately transferred onto two regeneration media (Table 5) for shoot induction. Although the
Table 4. Efficiency of callus induction on tested media

\begin{tabular}{llll}
\hline Medium & No of explants & Explant survival rate $(\%)$ & Explants producing calluses (\%) \\
\hline Experiment 1 & & & \\
C & 420 & $97.1 \mathrm{a}$ & $79.7 \mathrm{a}$ \\
S45 & 320 & $55.3 \mathrm{~b}$ & $0.0 \mathrm{~b}$ \\
SH & 530 & $97.2 \mathrm{a}$ & $80.0 \mathrm{a}$ \\
PVP & 430 & $98.6 \mathrm{a}$ & $69.8 \mathrm{a}$ \\
CH & 440 & $98.00 \mathrm{a}$ & $48.9 \mathrm{c}$ \\
Experiment 2 & & & \\
C & 210 & $97.6 \mathrm{a}$ & $81.4 \mathrm{a}$ \\
SH & 210 & $97.6 \mathrm{a}$ & $79.1 \mathrm{ab}$ \\
FH & 180 & $97.8 \mathrm{a}$ & $73.3 \mathrm{ab}$ \\
H30 & 210 & $96.2 \mathrm{a}$ & $73.3 \mathrm{ab}$ \\
IM & 210 & $98.6 \mathrm{a}$ & $69.5 \mathrm{bc}$ \\
\hline
\end{tabular}

Means followed by different letters within the column were significantly different at the 0.05 significance level according to the Kruskal-Wallis test 


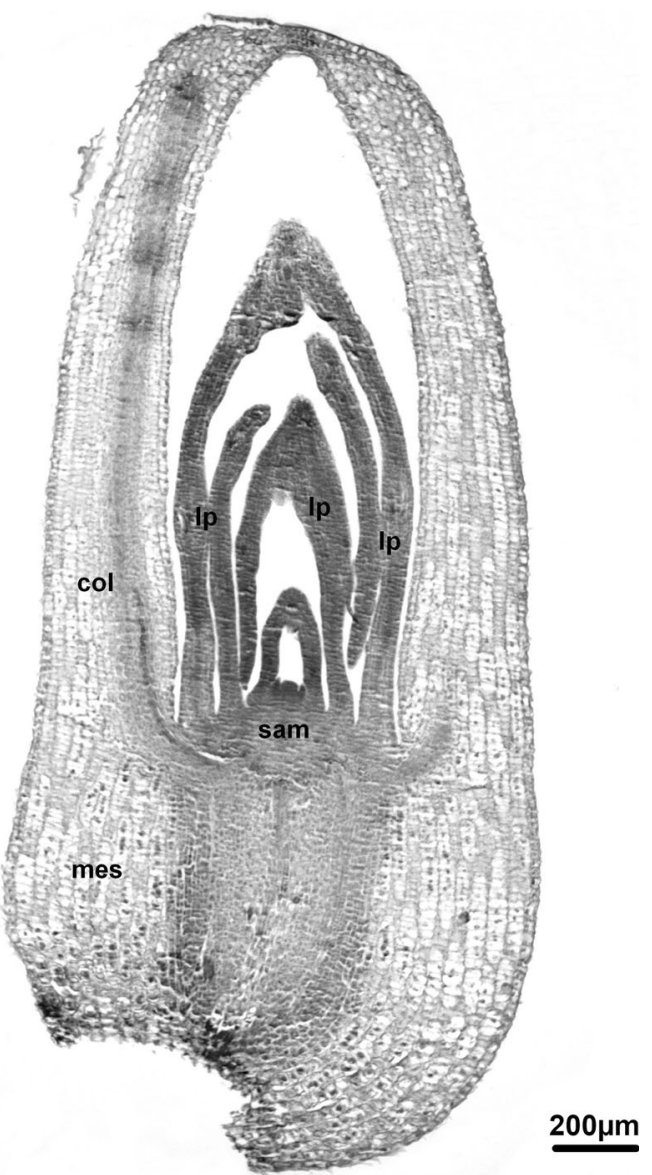

Figure 2. Explant after $5 \mathrm{~d}$ of incubation on SH medium; sam shoot apical meristem, $l p$ leaf primordia, col coleoptile, mes mesocotyl.

survival rate was relatively high (96-79\%), only a small percentage of calluses regenerated shoots (Table 5). The
SH-callus achieved the best regeneration rates: $34 \%$ and $39 \%$ on R1 and R2 media, respectively, and it was significantly higher than other callus-regeneration rates (Table 5). The total regeneration rate (counted as $\mathrm{R} 1+$ R2) for SH-callus (36.7\%) was almost four times higher (statistically significant) in comparison to the control $(9.4 \%)$. There was no statistically significant difference between regeneration rates recorded for R1 and R2 media. The average number of shoots per explant was $4.23( \pm$ 2.50 SD). Shoots regenerated from the $\mathrm{SH}$-calluses were transferred into rooting medium (RT, Table 1, Fig. 1e). Approximately, $90 \%$ of the shoots developed roots and $92 \%$ of the regenerants survived after acclimatization (Fig. 1f).

Optimization of media supplementation with honey (Experiment 2) In this experiment, five induction media were tested. We used medium with honey and sucrose ( $\mathrm{SH}$ ) and the $\mathrm{C}$ as previously described, and three other media: H30 medium with honey instead of sucrose, $\mathrm{FH}$-with filtered honey $\left(15.0 \mathrm{~g} \mathrm{~L}^{-1}\right)$, and IM-with sugars imitating the composition of natural honey. The percentage of explants producing callus was in the range of $81.4-69.5 \%$ (Table 4). Although the explants' response varied between induction media, a statistically significant difference was noted only for the $\mathrm{C}(81 \%)$ and IM medium $(69.5 \%)$. SH- and FHcalluses displayed the best response, and the regeneration rates recorded on both R1 and R2 media ranged from $32 \%$ to $39 \%$ (Table 5). Although, there were no statistically significant differences between two regeneration media, both $\mathrm{SH}$ and $\mathrm{FH}$ total regeneration rates (counted for R1 + R2) were significantly higher in comparison to other calluses.
Figure 3. Explant forming callus from leaf primordia (lp) after 4 wk. on SH medium.

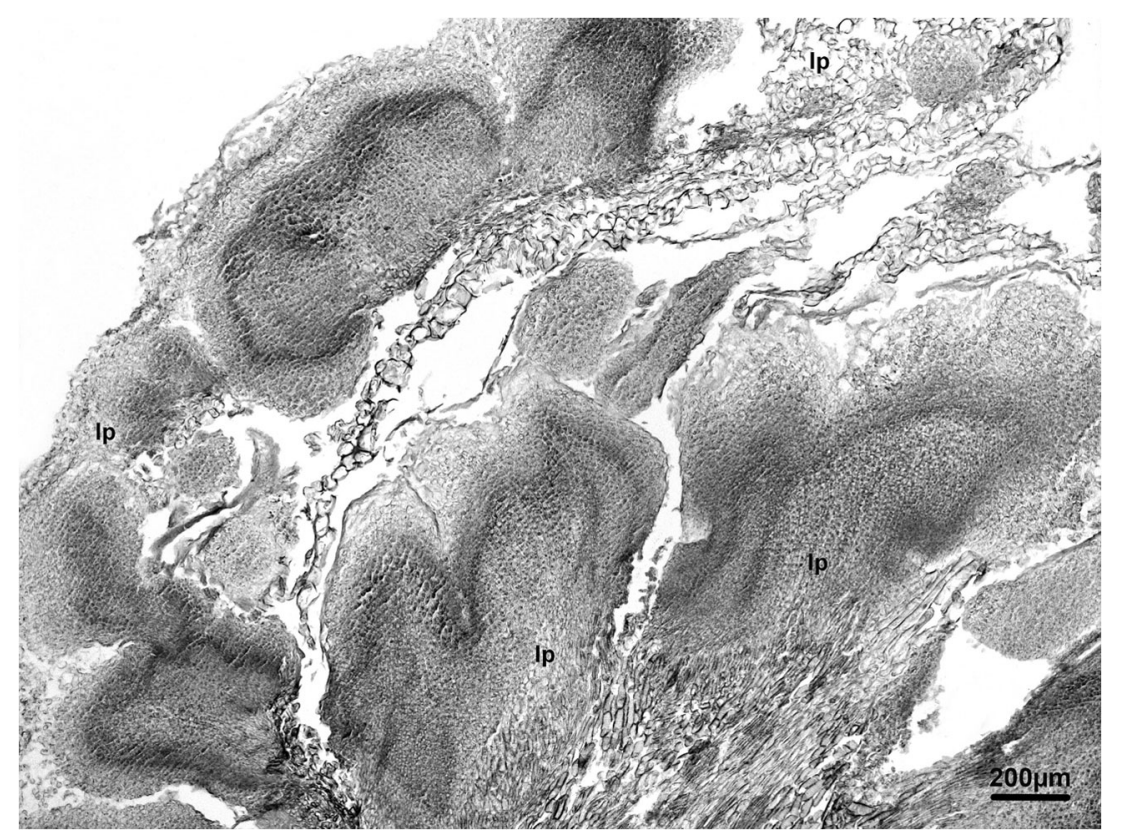


Table 5. Regeneration characteristics of calluses on $\mathrm{R} 1$ and R2 media

\begin{tabular}{|c|c|c|c|c|c|c|}
\hline \multirow[t]{2}{*}{ Callus induction medium } & \multicolumn{3}{|c|}{ Callus survival rate (\%) } & \multicolumn{3}{|c|}{ Callus regeneration rate $(\%)$} \\
\hline & $\mathrm{R} 1$ & $\mathrm{R} 2$ & Total \pm SD & $\mathrm{R} 1$ & $\mathrm{R} 2$ & Total \pm SD \\
\hline \multicolumn{7}{|l|}{ Experiment 1} \\
\hline $\mathrm{C}$ & $96.3 \mathrm{ab}$ & $87.5 \mathrm{abc}$ & $91.9 x y z \pm 10.33$ & $8.1 b$ & $10.6 \mathrm{bcd}$ & $9.4 x \pm 11.90$ \\
\hline $\mathrm{SH}$ & $96.3 \mathrm{a}$ & $91.0 \mathrm{abc}$ & $93.6 x \pm 9.59$ & $34.2 \mathrm{ac}$ & $39.0 \mathrm{a}$ & $36.7 \mathrm{y} \pm 20.82$ \\
\hline PVP & $88.6 \mathrm{abc}$ & $81.7 \mathrm{bc}$ & $85.4 \mathrm{y} \pm 11.74$ & $2.9 \mathrm{bd}$ & $0.8 \mathrm{bd}$ & $1.9 \mathrm{x} \pm 4.02$ \\
\hline $\mathrm{CH}$ & $89.2 \mathrm{abc}$ & $79.2^{\mathrm{c}}$ & $84.4 z \pm 11.21$ & $11.5 \mathrm{bcd}$ & $10.0 \mathrm{bcd}$ & $10.8 \mathrm{x} \pm 10.77$ \\
\hline \multicolumn{7}{|l|}{ Experiment 2} \\
\hline $\mathrm{C}$ & $91.3 \mathrm{a}$ & $90.0 \mathrm{a}$ & $90.6 x \pm 8.54$ & $12.5 \mathrm{a}$ & $25.7 \mathrm{a}$ & $18.8 \mathrm{x} \pm 15.44$ \\
\hline SH & $95.0 \mathrm{a}$ & $96.3 \mathrm{a}$ & $95.6 \mathrm{x} \pm 8.14$ & $36.7 \mathrm{a}$ & $39.2 \mathrm{a}$ & $37.9 \mathrm{y} \pm 19.70$ \\
\hline FH & $98.6 \mathrm{a}$ & $95.5 \mathrm{a}$ & $96.8 \mathrm{x} \pm 5.29$ & $32.4 \mathrm{a}$ & $34.1 \mathrm{a}$ & $33.2 x y \pm 18.05$ \\
\hline $\mathrm{H} 30$ & $97.4 \mathrm{a}$ & $92.5 \mathrm{a}$ & $94.9 x \pm 6.39$ & $15.3 \mathrm{a}$ & $18.8 \mathrm{a}$ & $17.0 \mathrm{x} \pm 20.00$ \\
\hline IM & $95.0 \mathrm{a}$ & $90.4 \mathrm{a}$ & $92.7 x \pm 7.43$ & $16.3 \mathrm{a}$ & $21.7 \mathrm{a}$ & $19.0 \mathrm{x} \pm 12.81$ \\
\hline
\end{tabular}

Means followed by different letters ( $\mathrm{a}, \mathrm{b}, \mathrm{c}, \mathrm{d})$ within the R1 and R2 columns, and by different letters (x, $\mathrm{y}, \mathrm{z})$ within total columns were significantly different at the 0.05 significance level according to the Kruskal-Wallis test
Results of honey analysis Examination of pollen composition revealed the multifloral origin of honey. Phacelia sp. and Brassica napus pollen grains were the most abundant (Table 3). Sugar composition was typical for multifloral honey. The main components - fructose and glucose-were predominant, while the content of the other sugars was less than $7 \%$ (Table 2). Total sugar content was about $81 \%$, which is an average value for multifloral honey from Poland (Kędzia and Hołderna-Kędzia 2008). Contents of proline $(44.0 \mathrm{mg}$ $100 \mathrm{~g}^{-1}$ ) and diastase number were within the Polish standard ranges (PN-88/A-77626)).

\section{Discussion}

In Experiment 1, $\mathrm{C}$ and the medium with sucrose and honey (SH) were the most efficient for callus induction. Regarding the percentage of explants forming callus, casein hydrolysate supplementation was the least efficient of all media. We found that composition of induction medium had an influence on the callus regeneration capacity. Addition of honey significantly improved the frequency of callus regeneration. The regeneration rate of SH-calluses on both regeneration media was almost four times higher compared to the control. The beneficial effect of honey and banana pulp on Miscanthus $\times$ giganteus callus and plant regeneration was reported by Płażek and Dubert (2010). Miscanthus, like Sorghum, is a C4 plant grown as raw material for biofuel production. Tissue cultivation of Miscanthus also faces the problem of intensive production of phenolic compounds, which affects callus growth and shoot regeneration. Płażek and Dubert (2010) improved the callus induction and regeneration rate of Miscanthus $\times$ giganteus by replacing sucrose $\left(30.0 \mathrm{~g} \mathrm{~L}^{-1}\right)$ with honey $\left(30.0 \mathrm{~g} \mathrm{~L}^{-1}\right)$ and banana pulp $\left(65.0 \mathrm{~g} \mathrm{~L}^{-1}\right)$ in the induction medium. The efficiency of plant regeneration was lower when calluses were induced on the medium with sucrose and transferred to regeneration medium with honey. The authors suggested that the carbon source should remain unchanged from callus initiation through the regeneration process. In our experiments on sorghum, the effect of the carbon source change was not sufficiently pronounced. Calluses successively obtained on various induction media were always divided into two equal groups and transferred to regeneration media containing sucrose only (R1) or supplemented with sucrose and honey (R2). There were no significant differences in survival rates and regeneration rates between those groups. It appears that presence of honey and sucrose in the induction medium $(\mathrm{SH}, \mathrm{FH})$ was crucial for a more efficient regeneration rate. In Experiment 2 the beneficial effect of honey in combination with sucrose appeared only for total regeneration rates. However, total regeneration rates for the $\mathrm{C}$ medium varied between our two experiments. This results mainly from the record on R2 medium (25.7\% Experiment 2, Table 5). The shift in the carbon source from callus induction (C medium, sucrose only) to shoot regeneration (R2 medium, $\mathrm{SH}$ ) could possibly give a positive result in this case. This is opposite to the effect described earlier in Miscanthus (Płażek and Dubert 2010). Experiment 1 was performed in late autumn, and Experiment 2 in late spring. The various response of callus on the R2 medium could be a result of the time separation of our experiments (approx. 6 mo). Subtle physiological differences between the autumn and spring plant material could have some influence on the regeneration rate. The seasonal variation in plant regeneration frequency was reported earlier for in vitro cultures with the explants derived from donor plants, which were grown under standardized and controlled environment. In barley, Sharma et al. (2005) observed such a variation when donor plants were grown in the growth 
chambers. In petal cultures of chrysanthemum, the seasonal effect on shoot regeneration appeared when donor plants were kept exclusively in vitro (Zalewska et al. 2011) or in an environmentally controlled greenhouse (Naing and Kim 2014). Various periods of honey storage have rather little effect on our results. The honey we used in both experiments met the Polish standard for multifloral honey, and all honey samples - stored at $4{ }^{\circ} \mathrm{C}$ were taken from the same production batch. It is known that honey compounds' stability decreases at higher temperatures (da Silva et al. 2016). It is also assumed that the formation of new compounds and the loss of some volatile components can appear over honey storage (Kaškonienè et al. 2008).

Combination of sucrose and honey gave a better effect than the use of these supplements separately. This finding is in agreement with previous results obtained by Płażek and Dubert (2010) for Miscanthus. The beneficial effect of honey might be partially related to limited browning of explants; although, we did not observe evident reduction of tissue browning. The browning of tissue is linked with enzymatic activity, mainly attributed to peroxidase (POD) and polyphenol oxidase (PPO) (Whitaker and Lee 1995). It is known that honey contains flavonoids and phenolic acids, which display antioxidant activity and prevent tissue browning (Oszmianski and Lee 1990; Hołderna-Kędzia and Kędzia 2006; da Silva et al. 2016). In Experiment 1, tissue browning was minimal, except S45 medium with increased concentration of sucrose (Fig. $1 b)$. The positive effect of honey was mainly expressed in the improved regenerative potential of calluses.

Honey contains more than 200 compounds (da Silva et al. 2016). It is a natural source of sugars, enzymes, amino acids, organic acids, vitamins, and minerals. Amino acids represent $1 \%(w / w)$ of honey composition, and their proportion depends on the origin of honey (da Silva et al. 2016). Analysis of the tested honey revealed its multifloral origin and typical composition for commercial honey from Poland. Content of proline $\left(440.0 \mathrm{mg} \mathrm{kg}^{-1}\right.$ ) represented the lower average value, which was in the range $311-$ $1232 \mathrm{mg} \mathrm{kg}^{-1}$ for Polish nectar honey (Kędzia and Hołderna-Kędzia 2008). Enzymatic activity expressed as Schade units of diastase number was mediocre and within the normal range. It is worth noting that during media preparation, the enzymatic activity of honey was inactivated by the sterilization process at high temperature. The heating of honey changes its composition and can lead to reduction of the nutritional value (da Silva et al. 2016). Furfural (5hydroxymethylfurfural) or Maillard reaction products are formed, which are markers of the deterioration process (Iglesias et al. 2006; da Silva et al. 2016). Keeping in mind the improvement of plant regeneration from callus tissue, we filtered honey (FH medium, Experiment 2) to avoid heating of honey and exclude formation of undesirable products. Even though we use $\mathrm{FH}$, the effect was comparable to SH-calluses. The fact that microfiltration did not improve the effect of honey can be explained by the effects of microfiltration on enzyme activity, amino acids abundance, and the vitamin content in honey. Rejection of the enzymes at the level of 26-66\% depending on the size of pores was recorded by Barhate et al. (2003). The majority of amino acids, such as aspartic acid and proline, are concentrated in pollen grains and during microfiltration their loss is significant - up to 90\% (Wilczyńska 2014). Proline is an amino acid which displays a multifunctional role in plants, including antioxidant capacity, osmoprotection, regulatory function, and cellular homeostasis controlling redox status (Szabados and Savouré 2010; Signorelli 2016). Vitamin content might also be reduced during the filtration process due to removal of pollen (da Silva et al. 2016). All these possibilities might contribute to the lack of improvement by FH. However, it does not explain which constituents of honey are responsible for its effect on regeneration. In Experiment 2, we used honey instead of sucrose (H30 medium) and the prepared sugar combination with fructose, glucose, and maltose (IM medium), but their effects were similar to the control. Only the combination of SH gave a synergistic effect and gained an improved regeneration rate.

Honey is not only a source of nutrients, hormones, polyphenols, and peptides of plant and animal origin. Also minerals are found in various types of honey (Kędzia and Hołderna-Kędzia 2008; da Silva et al. 2016). Potassium, sodium, calcium, and magnesium are the most abundant minerals in Polish honey (Kędzia and Hołderna-Kędzia 2008). Macroelements, microelements, and trace minerals present in honey might have a key role in morphogenesis of plant cells, tissues, and organs in vitro. In sorghum, complementary addition of nitrate ions and some amino acids to the media improved callus growth and proliferation (Elkonin and Pakhomova 2000; Liu et al. 2015).

\section{Conclusions}

A regeneration protocol for the sorghum cultivar Róna 1 using multifloral honey as a medium additive was developed. Combination of sucrose and honey in the callus-induction medium significantly improved regenerative capacity of callus. This is the first report on the beneficial effect of honey on the in vitro regeneration of sorghum. Further research on various sorghum genotypes and the effects of honey on plant in vitro regeneration are needed for assessment of the applicability of this protocol to mass propagation. One could expect high variation in the in vitro regeneration responses of sorghum (or other plants) to honeys of various geographical or seasonal origin. Therefore, a wide screening of honey types is worth considering. However, it will be a serious challenge to elucidate the most active compounds of honey due to high variability even in honeys of the same origin. 
Funding information The studies were funded by the Polish National Centre for Research and Development within the project PBS1/A8/0/ 2012. The authors are grateful to Prof. Henryk Burczyk (Institute of Natural Fibres \& Medicinal Plants) for providing the plant material.

Open Access This article is distributed under the terms of the Creative Commons Attribution 4.0 International License (http:// creativecommons.org/licenses/by/4.0/), which permits unrestricted use, distribution, and reproduction in any medium, provided you give appropriate credit to the original author(s) and the source, provide a link to the Creative Commons license, and indicate if changes were made.

\section{References}

Barhate RS, Subramanian R, Nandini KE, Umesh Hebbar H (2003) Processing of honey using microfiltration and ultrafiltration membranes. J Food Eng 60:49-54

Cai T, Daly B, Butler L (1987) Callus induction and plant regeneration from shoot portions of mature embryos of high tannin sorghums. Plant Cell Tissue Organ Cult 9:245-252

da Silva MP, Gauche C, Gonzaga LG, Costa ACO, Fett R (2016) Honey: chemical composition, stability and authenticity. Food Chem 196: 309-323

Elkonin LA, Lopushanskaya RF, Pakhomova NV (1995) Initiation and maintenance of friable, embryogenic callus of sorghum (Sorghum bicolor (L.) Moench) by amino acids. Maydica 40:153-157

Elkonin LA, Pakhomova NV (2000) Influence of nitrogen and phosphorus on induction embryogenic callus of sorghum. Plant Cell Tissue Organ Cult 61:115-123

Grootboom AW, Mkhonza NL, O'Kennedy MM, Chakauya E, Kunert K, Chikwamba RK (2008) In vitro culture and plant regeneration of sorghum genotypes using immature zygotic embryos as plant source. Int J Bot 4:450-455

Haccius B (1978) Question of unicellular origin of non-zygotic embryos in callus cultures. Phytomorphology 28:74-81

Hagio T (2002) Adventitious shoot regeneration from immature embryos of sorghum. Plant Cell Tissue Organ Cult 68:65-72

Hołderna-Kẹdzia E, Kẹdzia B (2006) Research on an antioxidant capacity of honey. Acta Agrobot 59:265-269

Howe A, Sato S, Dweikat I, Fromm M, Clemente T (2006) Rapid and reproducible Agrobacterium-mediated transformation of Sorghum. Plant Cell Rep 25:784-791

Iglesias MT, Martín-Álvarez PJ, Polo MC, de Lorenzo C, González M, Pueyo E (2006) Changes in the free amino acid contents of honeys during storage at ambient temperature. J Agric Food Chem 54: 9099-9104

Jensen WA (1962) Botanical histochemistry. WH Freeman and Company, San Francisco

Kaškonienė V, Venskutonis PR, Čeksterytė V (2008) Composition of volatile compounds of honey of various floral origin and beebread in Lithuania. Food Chem 111:988-997

Kędzia B, Hołderna-Kędzia E (2008) Skład chemiczny miodu. Ogólna zawartość cukrów. In: Kędzia B, Hołderna-Kędzia E (eds) Miód. Skład i właściwości biologiczne. Przedsiębiorstwo Wydawnicze "Rzeczpospolita" S.A., Warszawa, pp 51-110

Liu G, Gilding EK, Godwin ID (2015) A robust tissue culture system for sorghum [Sorghum bicolor (L.) Moench]. S Afr J Bot 98:157-160

Liu GQ, Godwin ID (2012) Highly efficient sorghum transformation. Plant Cell Rep 31:999-100
Maheswari M, Lakshmi NJ, Yadav SK, Varalaxmi Y, Lakshmi AW, Vanaja M, Venkateswarlu B (2006) Efficient plant regeneration from shoot apices of sorghum. Biol Plant 50:741-744

Mantovani C, Fernandes Lopes Pivetta KF (2016) In vitro development of Encyclea cordigera in different concentrations of honey. Cienc Rural 46:590-592

Murashige T, Skoog F (1962) A revised medium for rapid growth and bioassays with tobacco tissue cultures. Physiol Plant 15:473-497

Naing AH, Kim CK (2014) Seasonal effects on shoot regeneration from petal explants of chrysanthemum (Chrysanthemum morifolium) cv. 'Baeksun'. Curr Res Agric Life Sci 32:175-177

Oszmianski J, Lee CY (1990) Inhibition of polyphenol oxidase activity and browning by honey. J Agric Food Chem 38:1892-1895

Płażek A, Dubert F (2010) Improvement of medium for Miscanthus x giganteus callus induction and plant regeneration. Acta Biol Cracov Ser Bot 52:105-110

Polish standard of honey (PN-88/A-77626). http://www.opisik.pulawy. $\mathrm{pl} /$ lbjpp/normy.php

Raghavendra Rao RV, Pavan Kumar G, Subba Rao MV, Manga V (2000) Differential in vitro response of genotypes of Sorghum. Phytomorphology 50:253-226

Rao PS, Prakasham RS, Rao PP, Chopra S (2015) Sorghum as a sustainable feedstock for biofuels. In: Jose S, Bhaskar T (eds) Biomass and biofuels. CRC Press Taylor \& Francis Group, Boca Raton, pp 2-48

Regulation of the Ministry of Agriculture and Rural Development (Dz.U.09.17.94). https://www.prawo.pl/dz-u-akt/-/dokument/Dz.U. 2009.17.94/17518224/939084. Accessed 22 Jan 2019

Schade JE, Marsh GL, Eckert JE (1958) Diastatic activity and hydroxymethylfurfural in honey and their usefulness in detecting heat adulteration. Food Res Int 23:446-463

Seetharama N, Sairam RV, Rani TS (2000) Regeneration of sorghum from shoot tip cultures and field performance of the progeny. Plant Cell Tissue Organ Cult 61:169-173

Sharma VK, Hänsch R, Mendel RR, Schulze J (2005) Seasonal effect on tissue culture response and plant regeneration frequency from nonbombarded and bombarded immature scutella of barley (Hordeum vulgare) harvested from controlled environment. Plant Cell Tissue Organ Cult 81:19-26

Signorelli S (2016) The fermentation analogy: a point of view for understanding the intriguing role of proline accumulation in stressed plants. Front Plant Sci 7:1339. https://doi.org/10.3389/fpls.2016. 01339

Sudhakar Pola S, Mani NS, Ramana T (2008) Plant tissue culture studies in Sorghum bicolor: immature embryo explants as the source material. Int J Plant Prod 2:1-14

Szabados L, Savouré A (2010) Proline: a multifunctional amino acid. Trends Plant Sci 15:89-97

Whitaker RJ, Lee CY (1995) Enzymatic Browning and Its Prevention. ACS Symposium Series No 600, American Chemical Society, Washington

Wilczyńska A (2014) Effect of filtration on colour, antioxidant activity and total phenolics of honey. LWT Food Sci Technol 57:767-774

Wu E, Lenderts B, Glassman K, Berezowska-Kaniewska M, Christensen H, Asmus T, Zhen S, Chu U, Cho MJ, Zhao ZY (2014) Optimized Agrobacterium-mediated Sorghum transformation protocol and molecular data of transgenic sorghum plants. In Vitro Cell Dev Biol Plant 50:9-18

Zalewska M, Lema-Rumińska J, Miler N, Gruszka M, Dąbal W (2011) Induction of adventitious shoot regeneration in chrysanthemum as affected by the season. In Vitro Cell Dev Biol Plant 47:375-378

Zhong H, Wang W, Sticklen M (1998) In vitro regeneration of Sorghum bicolor (L.) Moench: efficient plant regeneration from shoot apices. J Plant Physiol 153:719-726 